\title{
СПЕЦИФІКА ФАЛЬСИФІКАЦІОНІСТСЬКОЇ МЕТОДОЛОГІЇ КАРЛА ПОППЕРА В ГУМАНІТАРНОМУ ТА ПРИРОДНИЧОМУ ПIЗНАНHI
}

\author{
Ю.А. Кушнір
}

\section{1 Вступ}

Сфера наукових інтересів Карла Поппера охоплювала дуже широке коло питань, починаючи з проблем методології і філософії науки, і закінчуючи проблемами епістемології і соціальної філософії. Зокрема, в своїх методологічних роботах Поппер здійснив спробу розв'язати низку складних завданнь, перед якими зупинились представники неопозитивізму, що належали до славнозвісного Віденського гуртка. Попперівське розуміння методології є по суті протилежним підходу, який $\epsilon$ характерним для неопозитивізму. Позитивісти не бажали визнавати існування будь-яких реальних проблем, окрім проблем «позитивних», дослідних наук. Філософські, гносеологічні, методологічні проблеми позитивісти вважали «метафізичними псевдопроблемами».

На думку Поппера, методологія не може бути ані логікою, ані емпіричною наукою, яка описує спосіб дій вченого-природознавця. Якби вона була однією з таких наук, то не змогла б відповісти на такі фундаментальні питання, що складають її предмет, а саме:

- що вважати емпіричною наукою;

• які принципи використовуються в науці;

Актуальні проблеми духовності 
- як проходить розвиток наукових теорій.

Теорія методу, на думку Поппера, не може існувати за рахунок простого опису існуючої наукової практики - в цьому випадку вона б відображала лише певний їі аспект або була б методологією якоїсь окремої науки $[4$, с. 150]. Виходячи з даного методологічного твердження, постає актуальне питання, що виражає проблему метода в гуманітарному та природничому пізнанні: чи можливе застосування спільних методів в зазначених галузях науки?

Деякі філософи стверджують, що методи (узагальнення, експеримент, новизна, тощо) природничих наук не можуть бути застосовані в гуманітарних науках, зокрема в соціології, в силу фундаментальної різниці між ними. Такої думки дотримуються так звані історицисти (Мілль, Конт, Маркс). «Фізичні закони, або „закони природи“, згідно історицизму, діють скрізь і завжди, бо фізичним світом править система єдиних зразків, незмінних в просторі та часі. Соціологічні ж закони, або закони суспільного життя, в різних місцях і в різні моменти часу не однакові» [8, № 8, с. 53]. Сам же Поппер виходить з універсальності розробленої ним методології, її однакової застосовності як в галузі фізичних, так і в сфері соціальних наук.

Таким чином, основне завдання нашого дослідження полягає в тому, щоб розглянути основні принципи методології Карла Поппера та їхню застосовність у царині гуманітарних і соціальних наук.

Загалом відношення до філософії Поппера не є однозначним:

- для одних, наприклад, вона стала, свого роду, символом, з яким пов'язані пошуки перспективної філософії та методології науки (І. Лакатос, Д. Міллер);

- для інших - це скоріше об'єкт теоретичного заперечення, в ході якого утверджуються нові концепції (Т. Кун, І. Бартлі, П. Фейєрабенд);

- треті-відхиляють її, обгрунтовуючи це тим, що вона відноситься до застарілого типу глобальної філософії, що не відповідає жорстким умовам лінгвістичної точності та доказовості (представники Віденського гуртка - Карнап, Вітгенштейн, Шлік) [10, c. 170$]$.

Весь цей дискурс точився за життя Поппера і має місце сьогодні в колі проблем наукового пізнання, методологіі, соціології, філософії, природничих, соціальних наук, серед яких найактуальнішими $є$ такі: 
- проблема співвідношення фальсифікаціонізму та верифікаціонізму;

- інтерпретація вірогідності;

- роль підтвердження теорій у розбудові наукового знання;

- значення побудови формалізованих мов для дослідження наукового знання;

- побудова логіко-методологічних концепцій, теорії наукового методу тощо.

Безпосередньою метою Поппера, особливо в ранній період його творчості, була побудова логічної теорії наукового методу. Причому, він виступав проти будь-яких проявів в науковому пізнанні елементів психологізму, апріоризму, інструменталізму, індуктивізму [6]. Метод «критичного раціоналізму» Поппер визначав як один з найголовніших для розвитку наукового знання, а «критерій демаркації»-як засіб відокремлення науки від метафізики, але в жодному разі не для елімінації останньої, на чому наполягали, зокрема, неопозитивісти. Ці проблеми тісно пов'язані як з природничими, так і з соціальними науками.

В нашому дослідженні ми ставимо собі за мету:

- розглянути основні принципи методології фальсифікаціонізму в її протиставленні індуктивному верифікаціонізму;

- звернути увагу на спільне та відмінне в природничому та гуманітарному пізнанні, зокрема, з огляду на методологічну проблематику Поппера;

- проаналізувати вирішення Поппером проблеми істини в науковому пізнанні.

\section{2 Основні принципи методології фальсифікаціоні- зму в її протиставленні індуктивістському вери- фікаціонізму}

Зазначимо, що порівнюючи методології фальсифікаціонізму та індуктивного верифікаціонізму, Поппер чітко займає позицію протесту щодо останнього: «Згідно широко розповсюдженим поглядам, проти яких я виступаю..., для емпіричних наук характерне використання, так 
званих, ,індуктивних методів“» [6, с. 46]. Індуктивісти стверджують, що істинність універсального висловлювання (гіпотези, теорії) спирається на «досвід». Але при цьому ясно, що опис будь-якого досвіду (спостереження або результату експерименту) може бути виражено тільки сингулярним висловлюванням і ні в якому разі висловлюванням універсальним. А отже, «універсальні висловлювання грунтуються на індуктивних висновках» [6, с.47]. Такий підхід, з позиції Поппера, є виключно індуктивістським, представники якого вважають, що для наукового методу немає нічого важливішого, аніж принцип індукції: «Цей принцип визначає істинність наукових теорій, - заявляє Рейхенбах. - Вилучення його з науки означало б . . . позбавити його здатності розрізняти істинність та хибність теорій» [6, с. 48].

Автор «Логіки наукового дослідження» стоїть на тому, що принцип індукції є хибним і веде до суперечностей, що є, свого роду, передумовою пошуку належної ознаки емпіричного, неметафізичного характеру теоретичних систем - «критерію демаркації» [6, с. 54].

Що стосується проблеми демаркації (розмежування), то він визначає її як проблему знаходження критерію, який дав би засоби для виявлення відмінностей між емпіричними науками з одного боку, та математикою, логікою і «метафізичними системами» - 3 іншого. «Знаходження вдалого критерію демаркації, - зазначає Поппер, - повинно бути завданням для будь-якої епістемології (теорії пізнання), яка не потребує допомоги індуктивної логіки» [6, с. 56].

Позитивісти, як правило, інтерпретують проблему демаркації натуралістично, так, якби вона була проблемою, що знаходиться в компетенції природничих наук. Замість того, щоб вважати своїм завданням знаходження вдалої конвенції, критикує Поппер, вони вважають, що потрібно сконцентруватися на відмінностях між наукою і метафізикою: намагаються довести, за виразом Юма, що метафізика - цілковите безглуздя [6, с. 56]. На думку Поппера, «це є знищення метафізики, а не демаркація» [6, с.57]. Така ж точка зору властива й поглядам Вітгенштейна, який стверджує, що «кожний вислів, який має відповідне значення, повинен бути логічно зведений до елементарних (атомарних) висловлювань, які розуміються ним як ,зразки дійсності“» [6, с.57]. Звідси, очевидно, випливає, що вітгенштейнівський критерій осмисленості співпадає з індуктивістським критерієм демаркації. Таким чином, Поппер підсумовує, що саме невирішеність проблеми індукції обумовлює, по суті, крах спроб позитивістів щодо вирішення проблеми демаркації.

На противагу концепції Віденського гуртка, Поппер не заперечує 
метафізику, він, скоріш, прагне сформулювати найбільш придатну специфікацію емпіричної науки або визначити поняття «емпірична наука» $\mathrm{i}$ «метафізика» таким чином, щоб стосовно кожної з наведених систем висловлювань можна було б стверджувати - ï дослідженням повинні займатися емпіричні науки, або ж ні.

\section{1 Фальсифікаціонізм як критерій демаркації}

Критерій демаркації, властивий індуктивній логіці, означає, що всі висловлювання в емпіричній науці повинні мати властивість, яка б давала можливість визначити їх істинність або хибність. Це означає, що розглядувані висловлювання повинні бути такими, щоб була можливість їх верифікувати та фальсифікувати. У зв'язку з цим Шлік, наприклад, стверджує: «Істинне висловлювання повинне допускати кінцеву верифікацію» (див. [6, с. 62]). Тобто вся суть наведених тверджень зводиться до того, що істинність одного чи іншого висловлювання можна сформулювати в ході його верифікаціі, інакше воно не має ніякого значення. Поппер наводить обгрунтування цього твердження Вайсманом: «Якщо не існує способу визначення істинності даного висловлювання, то воно взагалі втрачає будь-яке значення, оскільки значення висловлювання $є$ не що інше, як метод його верифікації» [6, с.62].

Сам Поппер виступає проти такого твердження неопозитивістів, зазначаючи, що індукції (окрім математичної) не існує взагалі. Тому виведення теорій із сингулярних висловлювань, верифікованих досвідом, логічно неприпустимо, що стимулює методолога до створення такого критерію демаркації, який може містити в межах емпіричної науки навіть такі висловлювання, верифікація яких неможлива. Ми не повинні вимагати можливості виділити деяку наукову систему раз і назавжди в позитивному (стверджувальному) розумінні, але зобов'язані вимагати від неї належної логічної форми, яка б дозволила (за допомогою емпіричних перевірок) виділити її як заперечувану [7, с. 63].

Загалом принцип фальсифікації означає наступне: до наукових тверджень відносяться лише такі, відносно яких можна знайти їхні «потенційні фальсифікатори», тобто положення, що їх заперечують, істинність яких встановлюється за посередництвом деяких загальноприйнятих процедур експериментального порядку [10, с. 171-172].

Свій принцип фальсифікаціонізму Поппер вважає, по-перше, найбільш доцільно логічним в ході досягнення основної мети науки - побудови емпірично змістовних теорій, які описують світ нашої чуттєвої дійсності, так як він приймає до уваги, що ні істинність, ні вірогідність 
загального твердження не може бути виведена з істинності кінцевого числа одиничних тверджень, чого не враховує принцип верифікації; по-друге, цей принцип випливає з пріоритету теорії, враховуючи те, що спостереження завжди опосередковані нею [4, с. 152].

З Попперівського розуміння принципу фальсифікації слідує те, що, хоча ми і не в змозі встановити істинність тієї чи іншої теорії, ми можемо - на основі раціональних процедур - визначити, коли ця теорія є хибною [10, с. 182-183]. Застосування «чистої фальсифікації», яка не в змозі заперечити дану теорію, дозволяє прийняти їі. Більше того, цю теорію, в даний момент, слід вважати наближеною до істини, хоча, в кінцевому результаті вона буде визнана хибною.

\section{3 Спільне та відмінне між природничим та гумані- тарним пізнанням}

Отже, проаналізувавши основний критерій відокремлення метафізичних вчень від наукового знання, торкнемося аналізу гносеологічних методів, з точки зору співвідношення між природничим та гуманітарним пізнанням.

Чітко та обгрунтовано ідею єдності методу всіх теоретичних або узагальнюючих наук Карл Поппер аналізує в своїй праці «Злиденність історицизму» [8]. Виходячи з тезису, що «науки використовують один і той самий метод, незалежно від того, які вони - природничі чи соціальні» [8, № 10, с. 42], Поппер наголошує на тому, що між методами теоретичних наук про природу та суспільство немає жодної різниці. Різниця існує між різними природничими та різними соціальними науками, але їхні методи є спільними, тотожними для кожної з них. Методи завжди передбачають дедуктивно-причинні пояснення та їх перевірку. Це називають іноді гіпотетико-дедуктивним або навіть гіпотетичним методом, оскільки він не дозволяє досягти абсолютної достовірності для наукових суджень, які перевіряються з його допомогою. Скоріше, ці судження зберігають характер пробних гіпотез, гіпотетичність яких, після багатьох перевірок, перестає бути очевидною [8, № 10, с. 42].

В силу такого попереднього характеру гіпотез більшість методологів вважає їх не остаточними. Поппер не погоджується з цим і стверджує, що в науці ми завжди зайняті поясненнями, передбаченнями, перевірками і що метод перевірки гіпотез завжди один і той же [8]. 3 гіпотези ми дедукуємо певний прогноз, який в подальшому співставляємо, якщо це можливо, з результатами експериментальних та інших 
спостережень. Погоджуючись з останнім, отримуємо підтвердження гіпотези, хоча й не остаточне її доведення; очевидне неспівпадіння вважається її запереченням, або фальсифікацією.

Результатом перевірок $є$ відбір гіпотез, які витримали випробування, або елімінація гіпотез - які не витримали його, тому були відкинуті. Тобто, головне завдання полягає в тому, щоб позбутися хибних теорій за допомогою перевірок. Таким є, по суті, метод тих наук, які спираються на досвід.

Тепер звернемося до відмінних рис методу в природничих та соціальних науках. Однією з важливих відмінних рис Поппер називає можливість прийняти в соціальних науках метод, котрий можна назвати методом логічної або раціональної побудови. Під цим автор розуміє метод побудови моделі за умови наявності повної раціональності всіх індивідів, що мають відношення до змодельованої ситуації [8, № 10, c.47]. Інша важлива відмінність - специфічні труднощі, пов'язані із застосуванням кількісних методів і, особливо, методів вимірювання.

Не менш важливим аспектом методології Поппера, відносно співвідношення природничих і соціальних наук, є критика ним історицизму (метод прогнозування людської історії). Заперечуючи антинатуралістичні доктрини історицизму, згідно з якими існує несумісність деяких методів, типових для фізики, з соціальними науками, в силу фундаментальних відмінностей між соціологією та фізикою, Поппер, по-перше, виступає як прибічник ідеї єдності методів в галузі зазначених наук, а по-друге, наголошує на високому рівні об'єктивності цих методів в соціології, що мають характер наукового пізнання. Для обгрунтування даного твердження знову звернемось до «Злиденності історицизму» [8].

В цій праці автор використовує такі поняття, як «часткова інженерія» та «холістська інженерія». Так зване «часткове полагодження» разом з критичним аналізом є основним шляхом до практичних результатів як в соціальних, так і в природничих науках $[8$, № 9, с. 2324]. Соціальні науки, в значній мірі, розвивалися завдяки критиці ідей соціального покращення, або, точніше, завдяки намаганням з'ясувати, чи зможуть окремі економічні або політичні події дати очікуваний або бажаний результат. «Цей підхід, - говорить Поппер, - що можна назвати класичним, я маю на увазі, коли говорю про технологічний підхід до соціальної науки, або про „часткову соціальну технологію“» $[8$, № 9, с.24]. Таким чином, говорячи про технологічні проблеми в соціальних науках, він поділяє їх на «часткові» та «державні» для того, щоб виділити відмінності між частковим та холістським (цілісним) 
підходами. Звісно це не означає, що акцент на практичному підході нівелює теоретичні проблеми. Навпаки, він $є$ найбільш продуктивним, оскільки породжує важливі суто теоретичні проблеми $[8$, № 9, с. 24].

Поппер $\epsilon$ прихильником методу «часткової інженерії» (поступові поетапні зміни, що ведуть до розвитку) в суспільстві, заперечуючи віру в можливість повної його перебудови (холізм).

Холістська, або утопічна соціальна інженерія, на відміну від часткової, носить завжди не «приватний», а «державний» характер. Ї̈̈ мета - перебудова суспільства в цілому. Холісти заперечують частковий підхід, вважаючи його надто поміркованим. Хоча при цьому, холістський метод виявляється незастосовним на практиці: чим масштабніші холістські зміни, тим серйозніші наслідки очікують їх несподівано та не заплановано, що, по суті, має наслідками неминучу часткову імпровізацію. Отже, Поппер приходить до висновку: «Шо стосується двох методів, я стверджую, що один з них можливий, тоді як інший просто не існує: він неможливий» $[8$, №9, с. 29]. Таким чином, елімінований має бути саме холізм, який аж ніяк не сумісний з принципом об'єктивності науки.

\section{4 Проблема істини в філософії Поппера}

На наш погляд, проблема істини $\epsilon$ невід'ємною від попередньо розглянутих проблем. Адже Поппер намагався розглянути її в контексті логічної теорії побудови наукового методу та росту наукового знання в цілому.

За твердженням Поппера, до того, як він ознайомився з теорією істини Тарського, у нього не було потреби в надто глибокому проникненні в суперечливі проблеми, пов'язані з використанням слова «істинне» [6, с. 336]. Поппер не заперечує того, що сам він, як і майже кожен, визнавав об'єктивну, або абсолютну, теорію істини як відповідності фактам, хоча і намагався не вживати цей термін.

Ситуація змінилася після появи запропонованої Тарським семантичної теорії істини. Оцінюючи позитивне в ній, Поппер акцентує увагу на реабілітації теорії відповідності, тобто теорії абсолютної або об'єктивної істини, до якої раніше відносився з підозрою [6, с.337].

Виходячи з розуміння теорії істини Тарським, Поппер бере цю теорію в основу свого вчення і приходить до висновку: «В методології науки нам потрібне поняття істини, як відповідність теорії фактам» [6, с.20]. Він виділяє деякі труднощі в розумінні такої теорії істини, 
які мають декілька витоків:

- по-перше, поєднання надзвичайно простої інтуїтивної ідеї з достатньо складною технічною програмою, яку вона породила;

- по-друге, широке поширення помилкової думки, згідно якої задовільна теорія істини повинна містити в собі критерій істинної думки, тобто обгрунтованого, або раціонального переконання.

Дійсно, три «суперниці» теорії істини як відповідності фактам теорія когеренції (істинність - це несуперечливість); теорія очевидності (за істину бере поняття - «відоме в якості істини») і прагматична (істина - це корисне) - всі вони, на противагу об'єктивній теорії Тарського, є суб'єктивістськими теоріями істини [6, с. 340].

Зазначені теорії є суб'єктивістськими в тому розумінні, що вони походять з принципово суб'єктивістської точки зору, яка пояснює знання як диспозицію, або як особливий вид віри, що характеризується, наприклад, своєю історією, або своїм відношенням до інших видів віри. Поппер стверджує, що можна показати намагання всіх суб'єктивістських теорій істини сформулювати такий критерій: «Вони намагаються визначити істину на основі походження або джерела нашої віри, на основі наших операцій верифікації, за посередництвом деякого різновиду правил прийняття віри, або просто через особливості наших суб'єктивних тверджень» [6, с. 340-341].

Всі вони, в тій чи іншій мірі, стверджують, що істина є те, що можна визнати, або в що можна вірити завдяки відповідним правилам, або критеріям, які відносяться до походження або джерела нашого знання, до його надійності або стабільності.

Об'єктивна теорія істини веде до зовсім іншої позиції. Це можна виявити з твердження, що дає можливість формулювати саме ця теорія, суть якого полягає в наступному:

- деяка теорія може бути істинною, навіть якщо ніхто не вірить в неї і навіть якщо немає причин для її визнання або для віри в те, що вона істинна;

- інша ж теорія може бути хибною, навіть за наявності порівняно непоганих підстав для ㄲï визнання.

Більш узагальнено можна констатувати, що «навіть тоді, коли ми наштовхуємось на істинну теорію, ми можемо тільки здогадуватись 
про це і для нас може виявитися неможливим пізнати, що це і є істинна теорія» [6, с. 341].

Однією з важливих переваг теорії об'єктивної, або абсолютної, істини в те, що ми шукаємо істину, але не знаємо коли буде можливість

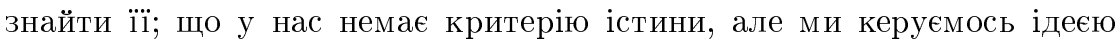
істини як регулятивним принципом; хоч і немає критерію істини, але $€$ критерій прогресивного руху (наближення) до неї. Звідси випливає, що істина, за Поппером, об'єктивно існує, вона носить вірогідний характер, а отже, в принципі недосяжна. Статус істини в об'єктивному розумінні - як відповідності фактам - і їі роль в якості регулятивного принципу можна порівняти з гірською вершиною, яка постійно вкрита хмарами, i, піднімаючись до неї, важко стверджувати, що в такій туманності буде досягнуто саме цієї вершини, а не будь-якої іншої. Тобто ця алегорія в науці означає, що об'єктивна істина існує, але проблема в тому, чи буде вона досягнута в абсолюті. Отже, сама ідея помилки або сумніву містить ідею об'єктивної істини [6, с.340].

Підсумовуючи наші роздуми щодо питання про істину, зазначимо, що Поппер визначає тільки об'єктивно, а не суб'єктивно існуючу істину, а також заперечує будь-яку можливість ㄲï абсолютного ствердження як диспозицію методом верифікації. Об'єктивна істина-це припущення, яке піддається фальсифікації, хоча й тимчасово, але це, свого роду, повинно виступати методологічним переконанням, що тільки за допомогою таких припущень ми матимемо надію знайти важливі істини [6, с. 349-350].

Щодо методології Карла Поппера, то вона, на нашу думку, не просто застосовна до гуманітарних та соціальних наук, а більше того, позбавляє соціологію від необгрунтованих прогнозів та пророцтв, підвищуючи таким чином об'єктивний фактор науковості гуманітарного знання.

\section{5 Бібліографія}

[1] Баженов Л.Б. Размышления при чтении К. Поппера // Вопросы философии. - 2002. - № 4. - С. 159-170.

[2] Кезин A.B. Р. Карнап и проблемы стиля философствования // Вестник МГУ. - 1993. - №6. - С.9-26. 
[3] Коркишко A.A. Рациональность как логическая проблема в социальной философии К.Поппера // Вестник Сев. ГГУ: Сб. науч. тр. - 1998. - Вып. 9. Философия и политология. - С. 3-8.

[4] Kузина E.Б. Учение о методе в эпистемологии Поппера // Логика методологического исследования. - М.; Изд. Моск. Университета, 1980. - C. $148-166$.

[5] Норманн Г.Э. К. Поппер о ключевых проблемах ХХ века // Вопросы философии. - 2003. - № 5. - С. 96-102.

[6] Попnер K. Логика и рост научного знания. Избр. работы / Пер. с англ., сост., общ. ред. и вступительная статья В.Н. Садовского. М.: «Прогресс», 1983.

[7] Поппер K. Логика социальных наук // Вопросы философии.1992. - № 10. - C. $65-75$.

[8] Поппер К. Нищета историцизма // Вопросы философии. - 1992. № 8. - C. 49-79; 1992. - № 9. - C. 22-48; 1992. - № 10. - C. 29-58.

[9] Садовский B.Н. О Карле Поппере и судьбе его учения в России // Вопросы философии. - 1995. - № 10. - С. 14-27.

[10] Юлина Н.С. Карл Поппер // Философы двадцатого века. СПб.-М.: Исскуство, 1999. - С. 167-187.

[11] Юлина Н.С. Философия Карла Поппера // Философия науки: Ежегодник. - М.: ИФ РАН, 1995.- С. 8-25. 